\title{
THE IMPACT OF TIME FACTOR IN OPERATIONS MANAGEMENT IN PUBLIC ORGANIZATIONS - CASE STUDY TAX ADMINISTRATION OF KOSOVO
}

\author{
Shefqet Dervishaj' \\ European University of Tirana, Tirana, Albania
}

\section{ABSTRACT}

Organizations exercise their activity in order to achieve their profit, while offering their products and services. Operations Management refers to the projection, operation and control of the process of transformation of inputs, such as human and material resources, into products or services that you offer to clients. The focus of this paper is the impacts of the time factor in the management of operations in public organizations, in particular the Kosovo Tax Administration (TAK).

TAK's mission is to collect revenues for the Kosovo budget and provide professional services to taxpayers so that taxpayers will enable voluntary fulfilment of tax obligations to compile the revenues for the Kosovo budget efficiently with lower cost. Operations Management at TAK is the process of realization of revenue and provision of services where the transformation process from inputs into outputs occurs. As inputs for this process is the staff or human resources, information, information technology, etc. whereas, output are revenues and services provided to tax payers.

The objective of this paper is to identify how employees manage time and how this factor affects the time to accomplish the purpose, and whether there is a set of standards regarding the planning and use of time.

Methodology used for this paper will be based on qualitative interviews and gathering empirical data about the plan and the realization of tasks, and how time is used as an important resource and thus how they can achieve its operational objectives.

\section{JEL CLASSIFICATION \& KEYWORDS}

- M10 M12 - OPERATIONS - TIME MANAGEMENT - PUBLIC ORGANIZATIONS — AUDITS

\section{INTRODUCTION}

The Tax Administration of Kosovo acts as an agency within the Ministry of Finance. It was established on $17^{\text {th }}$ of January 2000 within the framework of Central Fiscal Authority which at that time was run by UNMIK. Since 2003 it operates within the Ministry of Finance. From an agency initially employing a small number of employees, the TAK has now grown into a modern agency and together with the Kosovo Customs is the main provider of the budget revenues of the Republic of Kosovo.

In this context, considering the importance of the TAK, the study focused on the impact of the time factor in the management of operations where services are provided, laws are implemented and where the professional appearance and demeanour of the unit directly dealing with the taxpayers is of high importance. Thus, the importance of operations management is great and it is an indicator on the entire performance of the Tax Administration and, on

'shefqetdervishaj@hotmail.com

www.journals.cz the other hand, professionalism leads to voluntary fulfillment of tax obligations, which is the motto of the TAK. The TAK has its clear organizational structure and within such structure an important place is occupied by the team in the operations department, which consists of $6-8$ tax officials and is supervised by a team leader.

The importance of team management in the operations department is great because starting from work planning, organizing the team; management and control must be conducted with the utmost care. The sensitivity of the nature of the work on the one hand consists of the legal obligations of the TAK in fulfilling the budget, and the other hand there is the taxpayer who is the contributor in filling of the budget; therefore, team management must be conducted with the utmost professionalism and competence.

The time factor is of special importance because if this factor is managed properly the success in operations management is undeniable. The mission of the TAK is to collect revenues for the Kosovo budget, provide professional services to taxpayers in order to enable them a voluntary completion of tax obligations and implementation of the same in a fair and consistent manner, as well as consolidation of tax laws in order to enable an efficient and low-cost collection of revenues for the Kosovo budget. Operations Management in the TAK is the process of realization of revenues and providing of services where the transformation of inputs into outputs occurs.

\section{Literature review}

Organizations perform their activity to gain profit or nonprofitable purposes only based on the "license" granted by the society to offer their product in a certain field by way of producing products or offering of services (Llaci, 2002). The term operations has a broad sense and it refers to all activities not only in manufacturing, providing services but also in public organizations (Llaci, 2002). Operations management refers to the design, operation and control of the transformation process of inputs such as human labour and material resources into products or services offered to clients.

The system takes inputs such as people, technology, equipment, material and information and transforms the same through processes, procedures and different labour activities into goods and ready-made services (Llaci, 2002).

Operations Management as the management of processes generating products, which transform inputs into products or services, is on the other hand a reflection of an ever-increasing importance that is being gained by the services sector. In manufacturing organizations production managers perform the function of managing of operations by conducting a quality check, checking the in-stock goods. Also, with organizations offering services, e.g. hotels, the function of managing operations is performed by managers of food, beverages, etc. So the function of managing 
operations is performed by managers who are directly involved in the process of manufacturing products or providing services

Regardless of the fact that an organization is oriented in production of products or offering of services, operations managers must be attentive of productivity and its problems. In a nutshell, managers of any level must be vigilant of productivity. The importance of productivity in increasing the welfare of the society is an axiom of international value (Llaci, 2002).

Productivity is the ratio between the output provided by a manufacturing system, or service provider system, and inputs utilized for the creation of the same.

Productivity, in a broader sense, measures the capability of human labour to carry out services. Thus, productivity would be the measure of capability for human labour to provide services. Meanwhile, it is convenient to each and every one to transform this capability in the function of capital, in terms of technical investment, which is left at the disposal of the human being. It is evident that the equalization of professional qualification with the work intensity, the importance of rendered services, meaning the product value, will change on the basis of invested capital. In this hypothesis, in a general manner and in support of the economic reality of the modern world, productivity will at the same time measure the ability of capital and that of labour to create value (Sylqa, 2003).

In order to manage the time, first of all the four "Ds" must be considered. The first " $D$ " has to do with desire of have the time under control. The second " $D$ " is the determination or decisiveness for practicing the time managing techniques. The third "D" is determination or persistence not to give up on already issued decisions regardless of the temptations. The four "D" is discipline to achieve the success. Time management must be transformed into a kind of lifetime practice (Brian Tracy, 2014)

Managers must be cautious that during the process of operations and in order to achieve the objectives, the strategic and operational ones, to be aware of productivity; and to achieve a satisfactory productivity goals should be set, then move from goals to the task, and set SMART goals (S-specific, M-measurable, A-attainable, R-relevant and T-time).

Time management is a discipline-oriented and rational economizing time as a resource by developing methods and techniques for efficient use of time (Zeqiri, 2006)

\section{The purpose and objectives of the paper}

Realizing that the problem of operations management is a problem that has a significant impact on the performance of business organizations which aim at gaining as great as possible profits and the goal of public organizations is to provide as effective as possible services, in this context, what is the impact of the time factor in the management of operations.

The purpose of this paper is to carry out analyses on how the process of managing operations is conducted in Tax Administration of Kosovo:

- the first objective is to carry out analysis of the current management of operations, strengths and weaknesses;

- analysis of time as a very important resource;

- research of quantitative data with regard to use of the working time, and

- generating conclusions and providing recommendations.

www.journals.cz

\section{Methodology}

In completion of this paper a methodology was used which consisted of a combination of qualitative interviews which provided a outlook on how the process of operations management is conducted and where does the importance of the time factor fall which is the main emphasis of this paper and the extraction of data with regard to use of work time. The data on the use of working time are taken from the Tax Administration of Kosovo which is in possession of software recording the data of completed tasks that were foreseen according to the plan and the time elapsed in the performance of such tasks.

\section{Findings}

Operations Management in the TAK

The mission of Tax Administration is to collect revenues for the budget of Kosovo, which enable a fair and transparent financing. It depends on the taxpayers to voluntarily determine their exact tax obligation and to perform timely completion of that obligation. So, it is a mission to have to a maximum a voluntary completion of tax obligation by the taxpayers, providing professional services to understand their obligations and ensure proper and consistent implementation and strengthening of tax laws in order to efficiently and at low cost collect revenues for Kosovo budget.

Given that for Tax Administration product are revenues realized by taxpayer for Kosovo budget as well as providing services to taxpayers, Operations Management is the process through which those revenues and the providing of services are realized, where the inputs are transformed into outputs.

As inputs into this process of operations one can mention the personnel or human resources, technology, equipment, materials, information, etc. which are used by Tax Administration and the outputs are the revenues and services rendered to the taxpayers.

Although it has its own specifics, in this process special attention must also be paid to productivity, which in this case is the ratio between the engaged inputs and outputs. Having high productivity depends on the managerial skills of team managers to effectively manage the operations. For this reason, logical goals must be set which will reflect the team's real priorities, transformation of those goals into proper tasks for execution, then setting SMART objectives to warrant that the manager and the employee have common goals and the working time is managed properly while performing the operations. Setting SMART (S-specific, M-measurable, A-achievable, Are-relevant, T-time) objectives is a key managerial skill. The SMART objectives ensure that the employee and the manager both understand what the expectations are the employees can see how their objectives are listed compared to the objectives of the organization in the team level, functional level and in the highest organizational level. SMART objectives can be specifically used for the purpose of the employee's performance and the performance of the entire team; however, they can be used in everyday work in carrying out tasks and in achieving major and minor goals, as well.

Team Operations Management

In accomplishing the mission of Tax Administration the key role is with the team managers and their subordinates, which are the tax inspectors. The tax inspectors are in direct contact with clients of Tax Administration and they are the taxpayers. 
The accomplishment of the Tax Administration mission depends on the skills, competence, integrity, professionalism, transparency and respect towards the taxpayers and flexibility that the inspectors must be bestowed with, as well as on the managers' skills in coordinating, planning, managing, controlling, and managing changes.

In order to accomplish these goals, team managers have to determine their goals and set their priorities. Then out of goals specific tasks must be set, as well as objectives and above all an effective management of time and direct reporting is performed.

Settings objectives Successful operations management requires setting of proper goals which reflect the real priorities of a team that is directly involved in operations. All effective managers demonstrate this ability and estimate that the effective management of time and their talent, as well as their staff, is useless if not implemented towards achieving the necessary goals. Goals serve as a compass, pointing the way to things that managers and their staf should concentrate on, and to identify their goals and will know what is most important to accomplish on a daily, weekly and monthly basis. Setting goals is a formal process of defining the outputs worth of reaching. When goals are set, outputs must be agreed upon which can be accomplished by the manager personally or through his team.

By settings goals and measuring their achievements, team operations managers are able to:

- focus on what is more important;

- provide a unified management for his team;

- spend less energy on not so important tasks;

- avoid futile time;

- motivate themselves;

- overall strengthening of enjoying work.

Goals vary based on two aspects, on time frames and on importance. It is very important to understand how goals are categorized, so that they are not concentrated only on the right things, but the time and talent of the manager and the team are managed in compliance with the respective circumstances to ensure that the goals are achieved in the desired manner.

The team manager must make a kind of ranking of objectives ranging from the urgent, critical and then finally some goals that would be good to have. Urgent goals tend to have the manager's immediate attention, overloading his time as a manager and by better allocating resources for critical goals, because critical goals are more long-term goals as there is no need that they are achieved immediately. When distinguishing goals as per their importance, the manager will have a clear picture as to who should be given priority and then take decisions which will enable managers and their teams to dedicate more time to things that are more valid and this is the discipline for each effective manager.

Successful management of operations requires clear understanding of proper goals into appropriate tasks for execution in a manner that implements a logical order of ranking and prioritizing. Once goals are set, it must be moved on to identification of tasks, then set the schedule for completion of those tasks and finally get the work done.

Getting the work done goes through several steps. The first step, having objectives prioritized, the manageable tasks www.journals.cz must be identified and allocated along with the time required for completion of each and every task. The second step is prioritizing tasks from the highest priority to those of lesser importance. The third step is listing of tasks, meaning that tasks have a sequence; therefore, each task must be completed more or less before starting another. The fourth step is calculating the necessary time to complete the tasks or activities with priority that has been previously identified. Of course, a small percentage of grace period must be envisaged for some unpredictable problem.

\section{Effective Time Management}

Operations managers are personally effective and efficient in terms of how they spend their time. Having a clear understanding of priorities between that which is urgent and what is important, effective managers know where to spend their time more productively to enable them and their operations to realize their goals in achieving organizational success.

Time management is the discipline of organizing, allocating and controlling time that managers use for activities in order to achieve the desired results.

Managing time effectively generates benefits for the manager and the organization alike. This dedicates attention and energy to the activities that mostly support the objectives of the organization, interruptions are eliminated, and stress is avoided and/or reduced which may arise from the attempt to maneuver with many conflicting demands.

In order to manage working time, a diary of activities must be established, to show how to do each activity, to record the time will be spent in calculating even the smallest details. Then a check on how the working time was spent must be done. It must be outlined where the time was wasted, or better said, in secondary tasks, and to make remedies. Certainly, the planning and use of working hours should be as flexible as possible and not be rigid and enable managers to be more effective.

Building flexibility in working hours means that managers should spare more free time, to take note of the most important tasks. Greater flexibility will not make the day less busy, but will ensure that the manager has time to deal with the things that matter more.

Time management is a skill that requires practice and patience. Direct talks with workers regarding time and encouraging them to talk to each other and exchange ideas. Suggesting to employees to create and use the diary of activities, analyse the use of their working time and to come up with ideas to improve their time management. Frequent conversations with employees about their goals and to clarify time management, and support that reports be made based on a schedule and create list of tasks to be done.

While using the working time obstacles appear which must be identified where they come from and to identify a way to eliminate them which would enable effective management of working time. In order to manage working time one must pass through several steps as following. Firstly, the goals of the team must be identified and prioritized, then the goals must be broken down into manageable tasks, carry out analyses as to how work time is being spent currently, recognition of idle-timers, compiling the schedule, monitoring the improvement of the time management strategy.

Another very important element is also how an effective meeting with employees is carried out. Firstly, it must be ensured that there is meeting agenda, the meeting starts on time even if some participants are late, the meeting is held 
according to the agenda, the meetings should end with decisions and commitments by participants and participants are held accountable for their action tasks.

Empiric Data Containing Time Management - Time Management Analysis

In the yearly work plan in the operations department, the number and time for the types of visits is specified. Below is a table that tells how the effective time is calculated in this department.

Table 1: Calculating work days for a tax official of ATK in operations A. Calculation of working days of an employee:

$52 \times 5=260 \quad(52$ weeks $\times 5$ workdays $=260$ workdays

$260-22=238(260$ workdays -22 annual leave days $=238$

$238-8=230 \quad(238$ workdays -8 official holidays $=230$ workdays $)$

$230-7=223 \quad(230$ workdays -7 possible sick leave days $=223$

$223-6=217$ (223 workday -6 average possible training days =

217 days

(Mean working days of an employee during 2015)

B. Effective working hours for visits

\begin{tabular}{|l|l}
\hline 8 hour $(\mathrm{h})$ & (regular hours of work 08:00 - 16:00)
\end{tabular}

$8 \mathrm{~h}-1 \mathrm{~h}=7 \mathrm{~h} \quad(1$ hour lunch break 12:00 - 13:00)

$7 \mathrm{~h}-1 \mathrm{~h}=6 \mathrm{~h} \quad$ (1 hour of travel time - field visits)

$6 h-1 h=5 h \quad$ (1 hour filing, morning briefings, etc.)

5

$\mathrm{C} .=(\mathrm{A} \times \mathrm{B})$ Calculation of the effective working hours of an employee in 2015

\begin{tabular}{|l|l|}
\hline 217 & (mean working days of an employee during 2015) \\
\hline 5 & (effective hours for planning visits and inspections) \\
\hline 1085 & $\begin{array}{l}\text { (general fund of hours for an employee-inspector } \\
\text { during 2015) }\end{array}$ \\
\hline
\end{tabular}

Source: Detailed plan of treatment of risks for 2014, TAK (2014)

From the table above we can conclude that for 2014 the planned hours the employee must spend in visiting the taxpayers and the time required to perform inspections is 1085 hours of work. These working hours will be distributed to certain numbers of visits as well as inspections. From the overall plan $65.80 \%$ of hours are allocated for visits and $34.20 \%$ for inspections. This percentage has been extracted from the total visits (185291 total hours fund allocated for visits / 60,117 total plan visits = 3hrs average for a visit) because time is allocated for visits at large businesses which is 5 effective hours and for little businesses 2 hours and 30 minutes. For this case study I have taken the average hours for a visit which is 3 and inspection plan which is 4 (four) $x$ 93 hours $=372$ hours

Out of 1085 effective hours, 714 are for visits and 372 for inspections. If looking at general figures for all regions, it turns out that the effective time at disposal for visits is (253 employees $\times 714=180642$ hours) while for inspection is ( $253 \times 372=94116$ hours $)$

Table 2, I have presented the number of inspections planned and completed as far as the number of inspections and the hours spent for the certain period of time. All the empirical data are retrieved from the annual plan for 2014 while the implementation of inspections and hours spent is taken from the authentic documents.

The plan for realization of an inspection is 93 hours, whereas the realization took 104 hours (120547/1159). This means that we have a bigger expenditure of effective working hours for an inspection. Out of the time that is available for

\begin{tabular}{|c|c|c|c|c|c|c|c|}
\hline Region & $\begin{array}{c}\text { Planned } \\
\text { Inspections }\end{array}$ & $\begin{array}{c}\text { Planned } \\
\text { hours }\end{array}$ & $\begin{array}{c}\text { Total hours } \\
\text { for } \\
\text { inspections }\end{array}$ & $\begin{array}{l}\text { Implementat } \\
\text { ion of } \\
\text { inspections }\end{array}$ & \begin{tabular}{|c|} 
Average \\
hours \\
spent
\end{tabular} & \begin{tabular}{|l|} 
Total \\
spent \\
hours
\end{tabular} & $\begin{array}{l}\text { Percentage } \\
\text { of completed } \\
\text { inspections }\end{array}$ \\
\hline & 1 & 2 & $3(1 * 2)$ & 4 & 5 & $6\left(4^{\star} 5\right)$ & $7(4 / 1)$ \\
\hline Reg. 1 & 120 & 93 & 11160 & 131 & 121 & 15851 & 109.17 \\
\hline Reg. 2 & 108 & 93 & 10044 & 133 & 129 & 17157 & 123.15 \\
\hline Reg. 3 & 124 & 93 & 11532 & 131 & 120 & 15720 & 105.65 \\
\hline Reg. 4 & 120 & 93 & 11160 & 126 & 91 & 11466 & 105 \\
\hline Reg. 5 & 120 & 93 & 11160 & 106 & 115 & 12109 & 88.33 \\
\hline Reg. 6 & 164 & 93 & 15252 & 232 & 84 & 19488 & 141.46 \\
\hline Reg. 7 & 36 & 93 & 3348 & 55 & 96 & 5280 & 152.77 \\
\hline Reg. 8 & 116 & 93 & 10788 & 151 & 94 & \begin{tabular}{|l|}
14194 \\
\end{tabular} & 130.17 \\
\hline Reg. 9 & 104 & 93 & 9672 & 91 & 102 & \begin{tabular}{|l|}
9282 \\
\end{tabular} & 87.5 \\
\hline Total & 1012 & 93 & 94116 & 1159 & 104 & 120547 & 114.56 \\
\hline
\end{tabular}

Source: Annual plan and realization of the work, TAK (2014)

inspections, in total 141,174 hours scheduled for all regions, less time was spent in inspections, so they spent 120,547 effective work hours. This spent time was not managed well in most of the regions, just in case we have a shorter time for an inspection; and on the other hand, the number of completed inspections is much smaller than the planned ones. As it regards to the management of operations in this segment, there is stagnation due to time being ineffectively managed.

To analyse the management of the planned time and time spend in visits, I have selected three regions as the most representative ones and in each of the three regions I have selected a team where it was analysed the utilization of working time that was planned for the visits.

From the empirical data that have been obtained and from the carried out analyses I have concluded as following.

\begin{tabular}{|c|c|c|c|c|c|c|c|}
\hline \multicolumn{8}{|c|}{$\begin{array}{l}\text { Table 3: Planning and completion of visits for } 2014 \text { (sampled in } \\
\text { three teams - } 19 \text { inspectors from different regions) }\end{array}$} \\
\hline Team & $\begin{array}{l}\text { Visits } \\
\text { plan }\end{array}$ & $\begin{array}{c}\text { Planned } \\
\text { hours }\end{array}$ & $\begin{array}{c}\text { Total } \\
\text { hours for } \\
\text { visits }\end{array}$ & $\begin{array}{l}\text { Complet } \\
\text { ion of } \\
\text { visits }\end{array}$ & $\begin{array}{c}\text { Average } \\
\text { hours } \\
\text { spent }\end{array}$ & $\begin{array}{l}\text { Total } \\
\text { hours } \\
\text { spent }\end{array}$ & $\begin{array}{c}\text { Percent } \\
\text { age of } \\
\text { comple } \\
\text { ted visits }\end{array}$ \\
\hline 1 & 2 & 3 & $4(2 \star 3)$ & 5 & 6 & $7\left(5^{*} 6\right)$ & $8(5 / 2)$ \\
\hline Team A & 1428 & 3 & 4284 & 1633 & 2.51 & 4099 & 105.6 \\
\hline Team B & 1666 & 3 & 4998 & 1834 & 2.65 & 4860 & 120.76 \\
\hline Team C & 1428 & 3 & 4284 & 1284 & 2.45 & 3146 & 71.22 \\
\hline & 4712 & 3 & 13566 & 4751 & 2.54 & 12105 & 100.33 \\
\hline
\end{tabular}

Table 3 shows that the planned number of visits was accomplished $100.33 \%$. For these visits there were 12105 effective hours spent. Team $A$ has six employees and visits plan is ( 6 inspectors $\times 248$ visits $=1488$ ), Team B 1736 visits (7 inspector $\times 248$ visits) and Team C has 1488 planned visits $(6 \times 248)$.

From the results obtained from sampling of the population of 253 employees, where 19 of them have been analysed, their time spent in visits, it results that 2.54 units or 2 hours 32 minutes are required for a visit. If we take this as a result of the entire population then we have this expenditure of time as follows:

In Table 2, the hours spent for one inspection are 104 while on a visit 2 hours 32 minutes. Planned inspections are 1012 while realized inspections are 1159 . Planned visits are 60214 , planned time per visit is 3 hours.

Completed inspections are $1159 \times 104$ hours $=120.536$ working hours and completed visits are $52,436 \times 2 \mathrm{~h} .32 \mathrm{~min}$. $=133.187$ working hours

General plan of hours scheduled for visits $(60214 \times 3=180$ 642 working hours) and planned inspections (1012 × $93=$ 


\begin{tabular}{|l|l|l|l|}
\hline \multicolumn{4}{|l|}{$\begin{array}{l}\text { Table 4: Planned visits and inspections and their implementation } \\
\text { expressed in hours }\end{array}$} \\
\hline & Plan & Realization & Difference \\
\hline No. of visits & 60214 & 52436 & 7778 \\
\hline Effective hours & 3 & 2.54 & 0.46 \\
\hline $\begin{array}{l}\text { The visits hours } \\
\text { in total }\end{array}$ & 180642 & 133187 & 47455 \\
\hline $\begin{array}{l}\text { No. of } \\
\text { inspections }\end{array}$ & 1012 & 1159 & 146 \\
\hline $\begin{array}{l}\text { Hours for } \\
\text { inspections }\end{array}$ & 93 & 104 & 11 \\
\hline $\begin{array}{l}\text { Total inspection } \\
\text { hours }\end{array}$ & 94116 & 120536 & -26431 \\
\hline $\begin{array}{l}\text { Total effective } \\
\text { hours }\end{array}$ & 274758 & 253723 & 21035 \\
\hline Source: TAK, Compiled by author \\
\hline
\end{tabular}

94116 hours of work) in total results with $180642+94116$ $=274758$

Implementation of inspections $1159 \times 104=120547$, visits completed $52436 \times 2: 54=13187$ hours in total 253723 working hours. The difference between the planned effective hours 274758 and completed hours 260 498, it appears a difference from 21035 hours. The results of the data show that the working time was not used properly; thus, we can say that time is not managed well by the staff as well as by managers in operations.

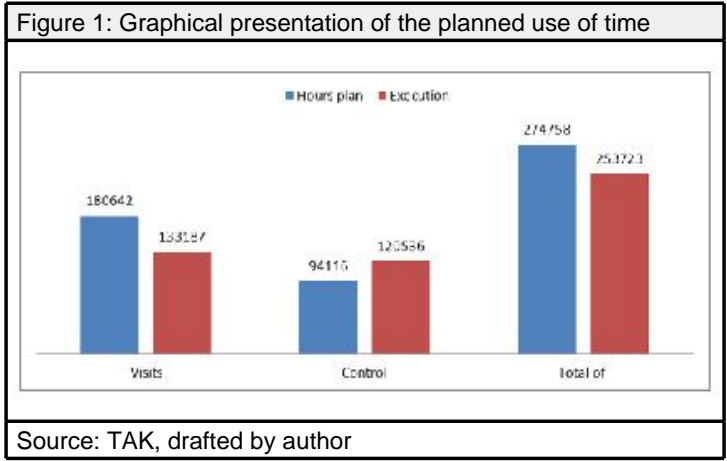

Table 1 indicates that we have a non-effective management of time because out of the planned total of 274.758 working hours, there are 253.723 justified working hours and we have 21035 lost hours. Converted into percentage, we have time used $92.34 \%$ and time lost $7.66 \%$. This lost time can have a negative impact on the accomplishment of operational objectives and the performance of TAK.

\section{CONCLUSION}

Based on the findings from the empirical data and on interviews with employees and managers we can draw the following conclusions.

Tax Administration of Kosovo, as an agency operating under the Ministry of Finance of the Republic of Kosovo, has a strategic plan from which are derived annual plans for the realization of its objectives and its mission is to provide quality services to taxpayers, and fulfillment of obligations of taxpayers to tax liabilities.

The annual plan for 2014 specified how many working days and how many effective working hours there are assigned for its employees. The focus of this paper is the operations department which is the largest in number and the biggest in importance because revenue is realized through this department.

www.journals.cz
Time available is 274.758 effective working hours for 253 inspectors which gives 1085 hours for one inspector. This is a very real planning because the weekend days are removed, annual leave days, holidays and training days; thus, leaving planned days for an inspector an average of 217 days. From one working day it was calculated that 5 hours are effective working hours $(217 \times 5=1085)$

By way of an operational plan it is determined that in all regions there must be carried out 60214 visits and time allocated for a visit is 3 hours $(60214 \times 3=180.642$ hours of work) and it is scheduled 1012 inspections and time allocated for one inspection is 93 hours $(1012 \times 93=94116$ hours).

The conducted analysis of the total realized hours, which in total is 253,734, resulted that time was not well spent, meaning that effective work time is not well utilized. So we do not have a good management of the work time. The interviews with employees and managers indicated that the reason for not using the time are very complex, ranging from motivation, holding long-lasting and in some cases unnecessary meetings, interference with various daily requests deviating from the operational plan, overloading with redundant formalities, untimely delegating of tasks, no feedback which has to do with communication, the impact of changes in legislation, the practice of carrying out tasks just before the expiry of the deadline, etc.

All these barriers have their impact in the management of time; however, according to my opinion, feedback and motivation mainly in salaries, are the main factors for poor time management. Lack of synergy where the right people are not in the right positions, is also one of the factors that affects the inefficient management of time and work.

Time management in general has its challenges. Taking into account the specificity of the analysed institution, which has restrictions on amending legislation, the impossibility of rapid movement and fast rendering of decisions, below I provide my recommendations.

While Tax Administration of Kosova has a detailed plan on time management, the employees must carry out analyses of work in time deadlines such as: daily, weekly, monthly, quarterly and semi-annually basis and they ought to be self-critics in identifying the reason for incompletion of work tasks.

Determination of individual values and understanding what is important for the employees. Pose questions to themselves as to why they work in that institution, why are they doing what they are doing. Therefore, they need to determine their purpose for their staying in the organization.

In order to manage the time, first of all the four "Ds" must be considered. The first "D" has to do with desire of have the time under control. The second " $\mathrm{D}$ " is the determination or decisiveness for practicing the time managing techniques. The third " $D$ " is determination or persistence not to give up on already issued decisions regardless of the temptations. The four "D" is discipline to achieve the success. Time management must be transformed into a kind of lifetime practice.

Identification and prioritization of goals, by listing and grouping them in levels of priorities such as very important, less important and the second hand ones which should be ignored.

The acceptance of clear guidelines, understanding tasks that should be done. 
Delegating of tasks on timely manner and to persons who can accomplish that work, caution must be paid not to delegate the duties to persons who can't finish that task.

Eliminating insignificant meetings that waste your time and reducing unproductive spending of work time, such as social activities, looking for unimportant things which can be avoided with a better organization at the work place, avoiding persons who tend to make long explanations and those who talk too much.

Taking notes on works that must be done and at the end of business hours, analysing completed tasks, to see where there is stagnation and to make improvements in following days.

Setting a routine, i.e. a program from the beginning of the working day until close of business and set a rule for work during working hours.

Identifying continuity in the event that the organizing of a day or a week proves successful, then the organizing of the following week should rely on the successfully closed week. It is always a good idea to build the foundations on something that success has already been proven on.

Presentation as realistic in setting the deadline for submission of a task, doing so not out of obligation but the realization made according to the plan is certainly more professional and less stressful.

\section{REFERENCES}

Llaci, Sh. (2002). Menaxhimi i operacioneve (Operations Management), Tirana, p. 377-398.

Sylqa, A. (2003). Produktiviteti në teorinë dhe praktiken ekonomike (Productivity in economic theory and practice), Pejë, p. 5-21.

Zeqiri, I. (2006). Menaxhimi (Management), Tetovo, first edition, p. $199-217$.

Tracy, B. (2014). Menaxhimi i kohës (Time Management), translated Alexander Koli, Pristina, p.3-7.

TAK (2014). Plani i detajuar mbi trajtimin e risqeve 2014 (Detailed plan of treatment of risks for 2014). Tax Administration of Kosovo Pristina, p. 72-78. Retrieved from: http://www.atk-ks.org/publikime/ raportet-vjetore

TAK (2014). Raporti vjetor i punës 2014 (Annual work report 2014), Tax Administration of Kosovo Pristina. Retrieved from: http://www.atkks.org/publikime/raportet-vjetore 